\title{
Identity Politics and Right-Wing Populism in Estonia: The Case of EKRE
}

\section{Vassilis Petsinis}

To cite this article: Vassilis Petsinis (2019) Identity Politics and Right-Wing Populism in Estonia: The Case of EKRE, Nationalism and Ethnic Politics, 25:2, 211-230, DOI: 10.1080/13537113.2019.1602374

To link to this article: https://doi.org/10.1080/13537113.2019.1602374

曲 Published online: 21 Jun 2019.

Submit your article to this journal $\llbracket$

View Crossmark data 


\title{
Identity Politics and Right-Wing Populism in Estonia: The Case of EKRE
}

\author{
Vassilis Petsinis \\ University of Tartu
}

\begin{abstract}
This case study focuses on Estonia and introduces the populist and radical right-wing party of EKRE (Eesti Konservatiivne Rahvaerakond/Estonian Conservative People's Party). It demonstrates that EKRE's employment of identity politics over the refugee question and immigration is embedded inside the pre-existing frame of Estonian restoration and "decolonization" nationalism. The party's campaign over the refugee question and immigration interlinks the collective memories of "colonization" under the Soviets with the collective anxieties of becoming "colonized" again by others in the future. This sociopsychological strategy has facilitated EKRE in augmenting its public appeal and consolidating its status as a potent actor in Estonian politics.
\end{abstract}

\section{Introduction}

This article casts its focus on Estonia and the party of EKRE (Eesti Konservatiivne Rahvaerakond/Estonian Conservative People's Party). EKRE, set up in 2012, delivered a satisfactory result in the last parliamentary elections (2015), garnering $8.1 \%$ of the vote and seven seats (Table 1). Its public appeal is on the rise and EKRE was Estonia's third most popular party throughout 2017 and 2018 (Tables 2a-2d). Since 2015, the refugee question has come to form a key component of EKRE's campaign. This acquires a greater significance considering that only 206 refugees from Syria and Iraq had settled in Estonia by March 2018. In addition to capitalizing on public insecurities over the arrival of refugees, the party previously voiced its opposition to Estonia's new Cohabitation Act (2016) and its provisions for LGBT rights. This article seeks to clarify how populist and radical right-wing parties adapt to specific national contexts and how the sociopolitical circumstances may provide opportunity structures for the emergence of populist and radical right-wing parties in certain countries and during certain periods. This requires a more extensive discussion of Estonian political culture as well as the particularities of its political history. The main questions addressed in this article are the following: What are the special features of EKRE as a populist and radical rightwing party within the Estonian context? How does the Estonian restoration and "decolonization" nationalism interweave with EKRE's opposition to the European Union (EU) refugee quotas?

The first part of this article (a) begins with a theoretical discussion of the distinctions and the main areas of concern within the populist and radical right, with a regional 
Table 1. Estonian parliamentary elections (March 2015).

\begin{tabular}{lc}
\hline Political parties & Percentages (seats) \\
\hline Reform Party & $27.7(30)$ \\
Centre Party & $24.8(27)$ \\
Pro Patria and Res Publica Union & $13.7(14)$ \\
Social Democrats & $15.2(15)$ \\
Green Party & $0.9(0)$ \\
EKRE & $8.1(7)$ \\
Free Party & $8.7(8)$ \\
Others & $0.9(0)$ \\
\hline Source: Estonian Electoral Commission, "Parliamentary elections 2015," http://rk2015.vvk.ee/ (accessed
\end{tabular}

Table 2a. Popularity ratings of political parties in Estonia (November 2018).

\begin{tabular}{lc}
\hline Political parties & Rate of popularity (\%) \\
\hline Reform Party & 25 \\
Centre Party & 22 \\
EKRE & 17 \\
E-200 & 9 \\
Social Democrats & 6 \\
Pro Patria and Res Publica Union & 5 \\
Green Party & 3 \\
\hline
\end{tabular}

Source: "Europe Elects," https://europeelects.eu/ (accessed 31 May 2019) (22-27 November 2018; 1, $000+$ respondents).

Table 2b. Popularity ratings of political parties in Estonia (January 2018).

\begin{tabular}{lc}
\hline Political parties & Rate of popularity (\%) \\
\hline Reform Party & 34.5 \\
Centre Party & 20.5 \\
EKRE & 18.4 \\
Social Democrats & 11.0 \\
Free Party & 5.4 \\
Pro Patria and Res Publica Union & 4.5 \\
Green Party & 4.5 \\
\hline
\end{tabular}

Source: "Kantar Emor Estonia," https://www.kantaremor.ee/ (accessed 31 May 2019) (18-25 January 2018; 1,107 respondents).

Table 2c. Popularity ratings of political parties in Estonia (August 2017).

\begin{tabular}{lc}
\hline Political parties & Rate of popularity (\%) \\
\hline Centre Party & 29.0 \\
Reform Party & 24.0 \\
EKRE & 12.0 \\
Social Democrats & 12.0 \\
Free Party & 6.0 \\
Pro Patria and Res Publica Union & 5.0 \\
Green Party & 4.0 \\
\hline
\end{tabular}

Source: Turu-uuringute AS, "August party ratings: Center Party ahead at 29 percent," https://news.err. ee/614623/august-party-ratings-center-party-ahead-at-29-percent (accessed 10 June 2018) (9-22 August 2017; 1,006 respondents).

Table 2d. Popularity ratings of political parties in Estonia (June 2017).

\begin{tabular}{lc}
\hline Political parties & Rate of popularity (\%) \\
\hline Reform Party & 25.4 \\
Centre Party & 25.1 \\
EKRE & 16.2 \\
Social Democrats & 14.2 \\
Free Party & 8.5 \\
Pro Patria and Res Publica Union & 6.6 \\
Green Party & 3.5 \\
\hline Source: Aili Vahtla, "June party ratings: Support for EKRE grows most, Reform and Centre tied," \\
https://news.err.ee/603178/june-party-ratings-ekre-now-third-most-popular-party-in-estonia (accessed \\
10 June 2018) (9-16 June 2017; 1,125 respondents).
\end{tabular}


focus on Central and Eastern Europe, and (b) analyzes the concepts of alien rule and ethnic democracy with a primary focus on the restoration nationalisms of Estonia and the Baltic States. Particular attention is paid to the aspects of universality and embeddedness. The main argument is that, on the one hand, EKRE largely matches the universal typology of a European populist and radical right-wing party: anti-establishment rhetoric; Euroscepticism; and strident opposition to immigration. Nevertheless, on the other hand, EKRE's employment of identity politics over the refugee question and immigration is embedded within the pre-existing frame of Estonian restoration and decolonization nationalism. The party's campaign interlinks the collective memories of "colonization" under the Soviets with the collective anxieties of becoming "colonized" again by others in the future. This socio-psychological strategy has facilitated EKRE in augmenting its public appeal and consolidating its status as a potent actor in Estonian politics.

In terms of methodology, this is a single-case study that suggests a general relationship in theory building. ${ }^{1}$ The scope of this article is primarily empirical and aims at strengthening the academic literature on right-wing populism in Estonia, the Baltic States, and, by extension, Central and Eastern Europe. The populist and radical right across the region has been attracting the interest of scholars, ${ }^{2}$ and this includes the Baltic States. ${ }^{3}$ Nevertheless, the increasing significance of new catalysts (namely, immigration and the controversies surrounding the refugee distribution debate) and their intersection with the populist and radical right in these societies provides an additional and urgent incentive toward the enhancement of the academic literature on the populist and radical right in the Baltic States. More important, the systematic capitalization on anti-immigrant sentiments by the populist and radical right throughout Central and Eastern Europe calls for updating and upgrading of the existing classification schemes for the European populist and radical right. This article demonstrates that populist and radical right-wing parties across Europe tend to capitalize on the socio-psychological appeal of the pre-existing traditions of nationalism within particular national settings. Therefore, a greater number of in-depth empirical studies on the operation of specific parties within specific countries are required.

This article relies on a qualitative and discourse analysis of EKRE's political program and other party documents (for example, electoral manifestos) as well as official statements and declarations. In addition, semistructured interviews were carried out with top EKRE affiliates and locally based academic researchers with an expertise in political sociology and Estonian party politics (conducted between 2016 and 2018). Quantitative sources such as public surveys have been of complementary importance, especially in highlighting the growth of EKRE's popularity over time. This article has also relied on relevant articles from the Estonian and international press. This material has been examined through the lens of the relevant academic literature.

\section{The populist and radical right in Central and Eastern Europe: Internal distinctions and primary areas of concern}

\section{Parties and issues}

The spectrum of the populist and radical right in contemporary Europe is highly diverse and idiosyncratic. Consequently, there is no universally agreed definition of what, 
precisely, constitutes populist and radical right-wing parties in the academic literature. One can sketch out the following features that are endemic in many populist and radical right-wing parties across Europe: (a) anti-establishment rhetoric and an overriding distinction between the people and the elite, ${ }^{4}$ (b) varying shades of Euroscepticism and nativism, ${ }^{5}$ and (c) insistence on the hard borders principle and law and order.

A series of academic experts on the populist and radical right ${ }^{6}$ have highlighted a qualitative difference between the political engagements of populist and radical right-wing parties in Western and Eastern Europe. Whereas within the former context, the primary emphasis is laid on anti-immigrant rhetoric, within the latter context, ethnic minorities are seen to assume the role of scapegoats for the populist and radical right. As Lenka Bustikova puts it, "In the more ethnically pluralistic societies, (populist and radical right-wing) parties seeking electoral support mobilize against constitutive, larger ethnic groups, with a high degree of politicization" (for example, the cases of Slovakia, Latvia, and Croatia). ${ }^{7}$ The author outlines three additional features that appear to demarcate East European populist and radical rightwing parties from their Western counterparts: (a) the assumption of left-leaning stances on the economy, (b) the association of minority rights with democratization (and, by extension, Europeanization), and (c) the frequent coexistence of populist and radical right-wing parties with "radicalized" mainstream ones in their national contexts. ${ }^{8}$

Economic grievances are intertwined with identity issues because of their solid correlation with national sovereignty and the capacity of nation-states to guarantee social welfare to their citizens. This necessity acquires a much higher importance when viewed in the context of the rapid privatization processes and the sets of austerity measures that were implemented across Central and Eastern Europe during the economic transition from communism. Hungary's Jobbik, in particular, has consolidated an economic platform ("Eco-Social National Economics") that includes calls for the renationalization of vital sectors of the economy. ${ }^{9}$ Less articulate "quasi-leftist" standpoints have also featured in the party programs of Ataka (Bulgaria), the League of Polish Families (Poland) and the Slovak National Party (Slovakia). ${ }^{10}$

Furthermore, the concretization of the adequate protection of the rights and freedoms of national minorities as one of the conditions for accepting post-Communist states into the EU (Copenhagen Criteria, 1993) ${ }^{11}$ forged a solid bond between minority rights, democratization, and Europeanization. ${ }^{12}$ In this light, and to a remarkable extent, the populist and radical right in the more ethnically pluralistic societies of Central and Eastern Europe started building their Eurosceptic platforms on varying allegations that the EU "imposes" minority rights from the exterior and weakens national sovereignty. ${ }^{13}$

The last decade has witnessed the phenomenon of "radicalized" mainstream parties throughout the region. Regardless of whether they are nominally center-left (for example, Slovakia's Direction-Social Democracy, SMER) or conservative/center-right (for example, Hungary's Civic Democratic Union [FIDESZ] or Poland's Law and Justice [PiS]), these parties have frequently defended their strident opposition to immigration along the lines of a cultural argumentation ${ }^{14}$ and/or introduced highly controversial policies regarding the rule of law and the separation of powers (mainly FIDESZ and PiS). This occurrence appears to have provided a trajectory, even if by default, for the flow of ideas largely espoused by the populist and radical right into the mainstream and the potential transformation of nominally mainstream parties. ${ }^{15}$ 
Focusing specifically on the Estonian context, Siim Trumm contends that anti-immigration sentiments and Euroscepticism were not of pivotal importance for the increased public support for EKRE in the 2015 parliamentary elections. ${ }^{16}$ Largely relying on quantitative data from a public survey conducted jointly by the Saar polling agency and Tartu University (March 2015), the author argues that the party's anti-establishment rhetoric and social conservatism had been a lot more topical for augmenting its popular appeal. ${ }^{17}$ Trumm summarizes the "average" EKRE voter as male and socially conservative with an anti-establishment disposition. ${ }^{18}$

This theoretical overview is of substantial importance in order to situate more accurately the sui generis character of EKRE's political engagement in the empirical discussion that follows. First of all, the party has been successful in incorporating a nexus that consists of domestic ethnopolitics, regional geopolitics, as well as "new" identity politics (that is, opposition to the EU quotas for refugees) into its anti-establishment and Eurosceptic platform. Second, although keen on financial protectionism and economic nationalism, EKRE does not conform to the model of a "quasi-leftist"/purely redistributive party in its economic agenda. Third, even though it originates from the structures of the (erstwhile center-right and rather prominent) People's Union of Estonia (Eestimaa Rahvaliit), EKRE does not fit the pattern of a "radicalized" mainstream party either. Lastly, as result of a "focus shift" since the second half of 2015, EKRE has been steadily augmenting its popularity by dominating the debate against the EU refugee quotas in Estonia.

\section{The notion of crisis}

The concept of crisis, as an active process, has been highly topical for the political engagement of populist and radical right-wing parties across Europe. According to Ernesto Laclau, "The emergence of populism is historically linked to a crisis of the dominant ideological discourse which is in turn part of a more general social crisis." ${ }^{\prime 9}$ In contemporary Europe, the new challenges that the migration crisis poses for several societies are indissolubly linked with the political crisis of liberal democracy and, more concretely, multiculturalism as the model for managing intergroup relations and diversity. In the first instance, one might argue that this correlation does not seem highly relevant within the context of the Central and East European societies because of the insignificant numbers of war refugees and/or other migrants therein.

Nevertheless, what possesses pivotal importance, on this occasion, are neither the causes nor the tangible symptoms of the social/political crisis but the successful endeavor of political actors to convince their target groups that there is a crisis. In Cas Mudde's words, “... there are very few concepts as vague as 'crisis'. People act politically not so much on the basis of actual facts, but of what they think is the truth. In that sense, crisis is important. When people think that there is an economic or a political crisis, they will act accordingly." 20 This brief conceptual discussion of crisis is necessary in order to set in context EKRE's socio-psychological campaign to (a) convince its target groups that Estonia also forms part of the European migration crisis and (b) highlight the pre-emptive character of its political engagement regarding the refugee question. 


\section{Alien rule and ethnic democracy: A conceptual overview}

\section{Alien rule: Central features and the Baltic/Estonian context}

In accordance with Michael Hechter, "at the most basic level, alien rule exists whenever one or more culturally distinct groups are governed by individuals of a different cultural group ... this encompasses the legally distinct situations of colonialism, foreign occupation and multiethnic states composed of some nations whose members consider their rulers to be alien." ${ }^{21}$ Alien rule contains an intrinsic controversy between governance and cultural distinctiveness that started becoming increasingly relevant after the emergence of the norm of national self-determination. ${ }^{22}$ According to the same author, cultural distinctiveness renders the acquisition of legitimacy, by the alien rulers over the ruled, a particularly hard task especially on occasions when the subordinate societies are culturally homogeneous. ${ }^{23}$ Hechter contends that a safer trajectory toward the legitimization of alien rule, throughout history, has consisted of the provision of collective goods, as well as a system of rational administration, from the rulers to the ruled. ${ }^{24}$

In the Baltic and Estonian contexts, a series of academic treatises tend to equate the historical experience of the Baltic States under the Soviets not solely with alien but, essentially, with colonial rule. Epp Annus sketches out three occasions on which military occupation can combine (or not) in space with colonization. These are (a) a temporary military occupation of a territory not accompanied by new settlements or continuing subordination, (b) a military occupation accompanied by exploitation of natural resources but without the significant establishment of settlers' colonies (for example, British India), and (c) a military occupation accompanied by the settlement of new inhabitants into the area and the exploitation of local resources (for example, French Algeria). ${ }^{25}$ Despite the tangible differences with the overseas dominions of Western colonial powers, Annus contends that the case of Estonia under Soviet rule largely matches the third pattern. ${ }^{26}$

Kalev Kukk argues that the Soviet era in Estonia included the essential features of colonial rule, such as (a) liquidation of the earlier economic structure, (b) establishment of a production structure corresponding to alien interests, and (c) migration and employment policies directed toward the assimilation of the indigenous population. ${ }^{27}$ One central actor in Estonia's post-Soviet nation-building is the Soviet-era settlers who often came to be depicted, en masse, in the domestic decolonization narratives as "the colonizer." 28 This conceptual discussion of alien rule and its Baltic/Estonian adaptations is required in order to clarify how and why EKRE, (a) at an early stage, embedded these pre-existing narratives of colonization into its political platform and, (b) in the longer run, has been combining these narratives with its opposition to the prospective colonization (that is, the refugee quotas) that is allegedly sponsored by a new "alien ruler" (that is, the EU).

\section{Ethnic democracy and its Baltic/Estonian specificities}

Due to the limitations in space, primary attention is paid to the conceptualization of ethnic democracy by Sammy Smooha. Based on the Israeli precedent, Smooha defines "ethnic democracy" as an arrangement that "combines a structured ethnic dominance 
with democratic rights for all." ${ }^{29}$ In greater detail, ethnic democracy is "democracy that contains the institutionalization of dominance of one ethnic group ... the 'democratic principle' provides equality between all citizens and members of the society while the 'ethnic principle' establishes preference and dominance." 30 Therefore, although providing the formal representative institutions of liberal democracy, ethnic democracy tends to restrict the participation of certain minority groups in the political processes.

By contrast to other contested (for example, Croatia) or negotiated (for example, Slovakia) acquisitions of independent statehood, Estonia and the other two Baltic States officially declared their independence as part of the restoration of their interwar statehoods (1991). This restoration aspect enhanced the essence of symbolic decolonization in Estonian nationalism. ${ }^{31}$ The removal of the vestiges of the Soviet past and the construction of a firmer continuity between the interwar and the contemporary Estonian statehood emerged as a top necessity.

Therefore, in accordance with the ethnic democracy model, the state institutions of Estonia (also Latvia) have been fashioned in such a way as to mirror the "ethnic state of the Estonians," finally restored after its suppression by the Soviets, with an overriding emphasis on the primacy of the Estonian language in the state bureaucracy and the public sector. ${ }^{32}$ In addition to domestic ethnopolitics, within the contexts of post-Soviet Latvia and Estonia, the ethnic democracy model has been legitimized as part of the endeavor to guarantee the continuous survival of the titular nations in an insecure international environment and in light of Russia's leverage as the external homeland for ethnic Russians. ${ }^{33}$ This conceptual overview is necessary in order to comprehend the incorporation of the nexus, which consists of domestic ethnopolitics and regional geopolitics into EKRE's political program since the party's early beginnings.

\section{Introducing EKRE: Formation process and political principles}

\section{Trajectory of formation}

EKRE came into existence in 2012 as the evolution of the merger between the formerly center-right People's Union of Estonia (Eestimaa Rahvaliit) ${ }^{34}$ and the more nationalistic and Eurosceptic pressure group Estonian Patriotic Movement (Eesti Rahvuslik Liikumine). In 2011, the remainder of the People's Union commenced talks with the Estonian Patriotic Movement, which also included EKRE's vice-chairman, Martin Helme. By that time, Mart Helme's (EKRE's current leader and Martin Helme's father) nationalist faction had taken over the People's Union. In EKRE's founding declaration, proclaimed in the central Estonian town of Põltsamaa (24 March 2012), the leadership of the new party vowed to protect the national interest, preserve Estonian traditions, and "... offer a viable alternative to the voters who are sick of the forced choice between Andrus Ansip (the then leader of the centre-right liberal Reform Party/Eesti Reformierakond) and Edgar Savisaar (former leader of the, nominally centrist/centre-left, Centre Party/Eesti Keskerakond), East and West, left and right." 35

The political circumstances provided the opportunity structure for the emergence of a new populist and radical right-wing party. Until then, the far-right end of the party spectrum had been occupied by the Estonian Independence Party (Eesti Iseseisvuspartei). This party never managed to win more than $0.5 \%$ of the vote, largely 
as result of its extremist profile and the unrealistic conceptualization of Estonia as a "neo-autarkic geopolitical space" between the EU and Russia. ${ }^{36}$ Moreover, the institutional framework did not provide financial incentives for parties garnering less than $1 \%$ of the vote and the $5 \%$ threshold made it difficult for smaller parties to win seats in parliament. ${ }^{37}$ The embedment into the pre-existing structures and power base of the People's Union enabled EKRE to bypass these obstacles in that the new party would not have to commence its engagement from scratch. ${ }^{38}$ Furthermore, EKRE swiftly filled the political gap that existed as a consequence of the Pro-Patria and Res Publica Union's transformation from a vocally nationalist actor, with a highly apprehensive outlook on the ethnic Russian minority, into a "moderately nationalist" party of the center-right. ${ }^{39}$

EKRE's evolution from within the pre-existing frame of the People's Union somewhat resembles the model of a "radicalized" mainstream party. Nevertheless, since EKRE's early beginnings, its leadership never regarded the party as even a substantially reformed continuation (or successor party) of the People's Union. In Martin Helme's words,

A sequence of leaderships in the People's Union had been involved in corruption scandals ... the "real" history of EKRE commences in 2012 when the People's Union merged with the Estonian Patriotic Movement ... we called for a decisive break from the corrupt past and demanded that a brand new party with a new name and a new political platform is set up. ${ }^{40}$

The participation of the Estonian Patriotic Movement in EKRE infused the new party with a more youthful element that enhanced its mobilization potential and projected a more "realistic" variant of Euroscepticism in comparison to the one espoused by the Estonian Independence Party until then. Most important, the Estonian Patriotic Movement undertook the principal coordinating role toward (a) structuring EKRE as a brand-new populist and radical right-wing party with a vocally anti-establishment orientation and (b) severing any apparent links to the People's Union as an "old" party that also formed part of the ("corrupt") establishment in the past.

\section{EKRE: A populist and radical right-wing party that operates in Estonia}

The key objective in this section is to set in context EKRE's universality vis-à-vis its embeddedness. In other words, the primary objective is not to merely illustrate how EKRE displays universal features of the European populist and radical right but rather to highlight what is "Estonian" in the ways that the party conforms to this typology. This will help signpost the reader more solidly toward comprehending how and why EKRE has been embedding its campaign into the pre-existing political culture of Estonian nationalism.

The systemization of anti-establishment speech makes up one of the most "essentially" populist components in the party's engagement. EKRE participated in the debates for the formation of the new government after the rift between the Reform Party and the Social Democrats (SDE) in November 2016 but did not make it into the halls of power. ${ }^{41}$ First of all, there seems to be an explicit cleavage between SDE and EKRE in most areas of policymaking. The cleavage between the two parties intensified after the last presidential elections (2016) and Martin Helme's firm opposition to the 
candidacy of Marina Kaljurand (former minister of foreign affairs) on the basis of her partly Russian and partly Latvian family background. ${ }^{42}$ Furthermore, the pact between the SDE and the Centre Party (the largest partner in the current government) was largely reached on the basis of the necessity to revise Estonia's neoliberal consensus and upgrade the welfare state. In this regard, EKRE's platform does not seem to fundamentally challenge the neoliberal consensus over the management of the economy and social welfare. ${ }^{43}$ This informal cordon sanitaire around EKRE has enabled the party to maintain the intensity of its anti-establishment rhetoric intact.

EKRE contends that "the current state of political affairs in Estonia favours the interests of specific segments within the society in a one-sided manner" and that it is characterized by an "excessive, often undemocratic, centralization of power with no independent vision of development." 44 EKRE's leadership also perceives institutions such as the media as part of the establishment. In Martin Helme's words, "Estonian state media are always loyal to the government and this provides them with an additional incentive to depict EKRE in a negative light ... the accusations of 'racism' that they often levy against us mean little to the Estonian people." 45 EKRE has frequently accused the "old" parties of opportunism and corruption. Certain specificities of the political landscape have, if only by default, facilitated the party's campaign. Despite the more tangible impact of the politics of consensus, in comparison to other postCommunist polities, Estonian politics have been revolving around a party system that is subject to fluidity and shifting loyalties. Parties with conflicting standpoints (for example, SDE and the Reform Party on the welfare state) have often watered down their disagreements in order to form coalition governments.

The crisis and dissolution of the previous government is indicative of these situational alignments and the absence of long-term consensus. ${ }^{46}$ To this one should add that, throughout the last decade, high-profile politicians have faced charges of corruption (for example, Edgar Savisaar during his tenure as Tallinn mayor). ${ }^{47}$ It is this intersection between malleability in policymaking and the perceptions of political corruption within the society that has enabled EKRE to build its image as "the only true anti-establishment party in Estonia." ${ }^{48}$ Empirical research demonstrates that the party's employment of anti-establishment speech has succeeded in striking a sensitive chord among its target groups. According to a survey conducted by the political sociologist Juhan Kivirähk for the Turu-uuringute AS agency (March 2018), anti-establishment rhetoric resonated with two-thirds of the party's voters, who also have low trust (indeed, the lowest level among all parties) in the parliament, government, and president. ${ }^{49}$

Euroscepticism forms another important component of EKRE's engagement with politics. EKRE's Euroscepticism includes three dimensions: geopolitical, economic, and sociocultural. One might argue that the embryonic origins of Euroscepticism in the Estonian society should be traced as early as the 1990s and the accession process to the EU. During that time, a series of public surveys detected that certain segments among the respondents prioritized Estonia's membership of NATO, on the basis of geopolitical and security concerns, over the country's accession to the EU. ${ }^{50}$ The geopolitical component of EKRE's Euroscepticism appears to have relied on this longer trajectory, concretized it, and updated it in accordance with the present circumstances. Correspondingly, EKRE holds that the core states within the EU allegedly underestimate 
the security threat that Russia represents for the Baltic States. The party contends that by contrast to (former President) Toomas Hendrik Ilves' expectations, membership of the EU did not enhance Estonia's security status vis-à-vis Russia. ${ }^{51}$ Moreover, EKRE expresses its discontent over Germany's alleged apathy in light of Russian aggression and its ongoing cooperation with Moscow on energy issues. ${ }^{52}$

EKRE's economic Euroscepticism largely revolves around the party's opposition to Estonia's participation in the European Stability Mechanism. In the party's own words, Estonia's "forced" participation in the European Stability Mechanism is "unfair, immoral and undemocratic at the same time, yet it does not guarantee the stability and credibility of the Euro."53 Furthermore, economic Euroscepticism frequently intercedes in EKRE's program and other party documents with nativism and financial protectionism. EKRE deplores the way in which "Estonia has been partially transformed into an area representing the interests of the EU, foreign capital and career advocacy functionaries," ${ }^{54}$ demands the taxation of tax-free foreign capital, ${ }^{55}$ and objects to the acquisition of land by foreign nationals. This intersection among economic Euroscepticism, nativism, and financial protectionism should also be understood as part of EKRE's endeavor to maintain the party's grip on its predominantly rural electorate.

This claim is additionally substantiated through reference to EKRE's simultaneous calls for (a) the protection of domestic agricultural producers and the prioritization of their products in the market, ${ }^{56}$ (b) the increase of EU subsidies for Estonian agriculture, ${ }^{57}$ and (c) the protection of the rural environment ${ }^{58}$ and halting EU-funded infrastructure projects (Rail Baltic, in particular) with a potentially detrimental impact on nature. ${ }^{59}$ Lastly, the sociocultural component of EKRE's Euroscepticism revolves around the party's opposition to (a) the EU's guidelines for LGBT rights and to Estonia's Cohabitation Act $(2016)^{60}$ and (b) the EU's quota arrangement for the distribution of refugees.

With regards to its economic agenda, it becomes obvious that, unlike several other populist and radical right-wing parties across Central and Eastern Europe, EKRE cannot be categorized as a party with a "quasi-leftist"/purely redistributive stance on the economy. In combination with its more reserved outlook on social welfare, it appears that EKRE's financial protectionism and economic nationalism are primarily aimed at safeguarding the interests of (small- and medium-size) Estonian entrepreneurs inside the highly antagonistic context of globalized capitalism. One may contend that this more pro-free market disposition is a rather sui generis feature of the party's political engagement, which is highly specific to the Baltic/Estonian political and socioeconomic context. A series of academic experts have argued that even the neoliberal consensus on privatization (1990s) came to be seen as the vehicle that would enable the Estonian nation to "decolonize" from the Communist era planning and reassume full control over the management of their country's economy. ${ }^{61}$

EKRE's prerogatives on citizenship and immigration are structured in such a way as to interlink these two policy areas with the necessity to maintain Estonian-Russian relations securitized and the adoption of a stricter law and order approach. EKRE argues that the highest posts in the state administration must be reserved only for Estonian citizens by birth but does not object to the naturalization process of "stateless" persons. $^{62}$ However, naturalized individuals must give up any previous nationality and 
possess solely Estonian citizenship. ${ }^{63}$ Furthermore, EKRE's program dictates that the Estonian state must possess a complete and regularly updated registry of Russian nationals living in the country. ${ }^{64}$

With regards to immigration, EKRE's program specifies that "a fixed immigration quota must be set and a thoughtful action plan that ensures the fast integration of immigrants into Estonian society and culture must be implemented." ${ }^{25}$ The linkage between immigration policy and a law and order approach becomes particularly manifest in the following excerpt: "The residence permits of foreign nationals involved in hostile activities against Estonia must be repealed ... the state can take over repatriation costs to the countries of origin, in cooperation with international organizations, if required." 66

EKRE's party program was authored prior to the escalation of the refugee crisis since the second half of 2015. This means that these programmatic prerogatives on immigration alone would not suffice for the party to address the complex realities of the new state of affairs across Europe. Therefore, it started becoming evident that EKRE would need to shift its lens from "classical" areas of engagement (domestic ethnopolitics and the Estonian-Russian relations) to new ones (the refugee question and immigration).

\section{Capitalizing on the politics of anti-immigration}

\section{The refugee question in Estonia: General background and political reactions}

In accordance with the EU's quota arrangement, Estonia agreed to accommodate 58,080 relocated persons (September 2016). According to the Ministry of Interior, by March 2018, 206 of them were in the country and a refugee assistance center has been functioning in the locality of Vao (Lääne-Viru county). ${ }^{67}$ The refugee quota debate has generated controversies and engendered a "core versus periphery" cleavage within the EU: Germany versus the Visegrad Four (also Italy, the UK, etc.). Although not as vocal as their Central European EU partners, Estonia also expressed its reservations over the quota system.

In July 2016, Raivo Küü stated, on the Ministry of Interior's behalf, that "Estonia prefers case-specific decisions to the automatic redistribution of refugees by quota."68 As early as spring 2015, the entirety of the parties at the Riigikogu (Estonian parliament) had voiced several objections to the quota arrangement on the basis that Brussels had miscalculated Estonia's capacities. In former Prime Minister Taavi Rõivas's (Reform Party) words, "The EC had made an error in its calculation and even if Estonia did welcome the refugees, the quota should be much lower." ${ }^{69}$ Even the Social Democrats, otherwise highly sensitive to humanitarian issues, voiced certain reservations over the Commission's directive along the lines that Estonia did not possess adequate infrastructural capacities. Moreover, on 12 September 2016, the Centre Party and EKRE submitted two (rejected) draft resolutions to the Riigikogu. ${ }^{70}$ The Centre Party called for a referendum to set a maximum limit for the number of people eligible for asylum in Estonia. EKRE called for a referendum on Estonia's participation in the EU's migrant distribution plan. 


\section{EKRE's engagement over the refugee question: Political rhetoric and public appeal}

EKRE specifies that "Estonia's demographic realities do not allow mass immigration from any direction ... immigration must remain firmly under the competence of national legislation."71 As early as July 2015, Martin Helme dubbed the majority of asylum seekers "illegitimate refugees who are looking for social welfare," adding that "if we came to power, EKRE would deport them."72 Later, in the autumn, the party started its petition campaign for a referendum on the question of Estonia accepting refugees as a whole. $^{73}$

The party appears to have harmonized its campaign over the refugee question with the dominant mood in the public opinion. In June 2015, a survey commissioned by the Estonian Government Office and conducted by the TNS Emor agency found that $42 \%$ of the sample objected to the admission of refugees. ${ }^{74}$ Meanwhile, an opinion poll conducted jointly by the Turu-uuringute AS agency and Tartu University (November 2015) found that a mere $39 \%$ of the sample harbored no objections to the settlement of refugees in Estonia. ${ }^{75}$ Another survey, carried out by the same agency during the same month, found that $62 \%$ of the respondents held the opinion that the government cannot be trusted in its management of the refugee issue. ${ }^{76}$ It was only toward the end of 2016 that an opinion poll, commissioned by the Government Office, revealed somewhat more positive outlooks on the admission of refugees to the country (especially among the higher educated and younger respondents). ${ }^{77}$ Nevertheless, another survey conducted by Turu-uuringute AS for the Institute for Society Research (Tallinn; 16-30 January 2018) found that a majority of respondents felt that (a) Estonia should accept only a small number of refugees and (b) it would be a positive development if the refugees who arrived in Estonia left the country. ${ }^{78}$

The general apprehension vis-à-vis the refugee quota arrangement, across Estonia's party spectrum, does not seem to impact upon EKRE's engagement on this issue. The essential qualitative difference between this and the other parties consists in that EKRE is the only party that systematized and, to a considerable extent, "weaponized" its opposition to the EU refugee quotas through means of mass mobilization. As early as 6 February 2016, EKRE was intensifying and internationalizing its engagement via staging countrywide protests against "the Islamization of Europe" (including Germany's Pegida and other grassroots initiatives). ${ }^{79}$ Particular attention was paid to the wave of sexual assaults in Cologne on New Year's Eve 2016 and the ensuing "necessity to protect Estonian and European women." These incidents were interpreted as "the shape of things to come" for the entire continent, if Germany and Brussels insist on an "open border" approach to Muslim immigration. ${ }^{80}$

In contrast to the cases of FIDESZ, PiS, and/or SMER, the Estonian party spectrum does not include any "radicalized" larger parties with the desire to weaponize their reluctance toward the refugee quotas in a potential affront with the EU. This absence of contenders has enabled EKRE not solely to capitalize on the anti-refugee debate but also to anchor its campaign against the refugee quotas within the frame of its Euroscepticism and anti-establishment discourse in domestic politics. On the one hand, the party held the EU accountable for, once again, forcing its directives on Estonia in such a manner that it disregards and contravenes the will of the majority. ${ }^{81}$ On the 
other hand, the government is being held accountable for ignoring the "will of the people" and "lying to the public." 82

\section{Situating the present and the future inside the context of the past}

The causes of anti-immigrant sentiments may vary remarkably from one society to the other. Meanwhile, political parties and groupings that stress the hard borders principle tend to anchor their narratives primarily into symbols and imageries derived from their own societies' historical experiences. Locating the present, or occasionally the future, in the context of the past is a common technique among nationalist actors that helps interpret developments along a linear trajectory and satisfy the quest for meaning among their bases of support. ${ }^{83}$

The urgent necessity to repair the physical damage and reverse the psychological trauma inflicted on the Baltic nations during the Soviet era is repeatedly stressed by EKRE and its allied parties in the Baltic States. ${ }^{84}$ In the text of the "Bauska Declaration," signed jointly by EKRE, Latvia's National Alliance, and Lithuania's Nationalists' Union (2013), it is stated that "we stand firm to the demand of compensations for occupation by Soviet Communist regime ... acknowledgement of the occupation and full compensation for it should serve as a guarantee against any other occupation and aggression to recur."

As Siim Trumm puts it, "Electoral support for populist right-wing parties is influenced by their ability to tap on the 'right' type of disillusionment when choosing their public discourse." 85 With regards to EKRE, since the second half of 2015, it started becoming an imperative for the party's strategy to embed their opposition to the EU's refugee quotas within the colonization and decolonization narratives of Estonian nationalism. In particular, the refugee question often interweaves in the party's speech with concerns over the "(East) Slavic immigration to Estonia" 86 and the fears that this may result in "a new colonization and the demographic prevalence of Russian-speakers over Estonians in the next 30 years." ${ }^{87}$ As Toomas Hendrik Ilves subtly hinted, public reservations over the refugee question and immigration should not be disconnected from the colonization under the Soviets and its long-term ramifications. ${ }^{88}$ Therefore, identity and memory politics and their selective appropriation appear to have gained precedence over the minuscule presence of war refugees in Estonia and evolved into a key component in EKRE's engagement in Estonian politics.

Quantitative data hint that EKRE's engagement with the refugee question has succeeded in touching a sensitive cord among its target groups. A public survey conducted by Turu-uuringute AS (22-28 March 2016) detected a clear link between EKRE's capitalization on anti-refugee rhetoric (especially after the Brussels terrorist attacks on 22 March 2016) and the party's increase in popularity (Table 3). In accordance with the findings of this survey, EKRE's popularity jumped from an estimated 13\% to $19 \%$ immediately after the Brussels bombings. ${ }^{89}$ These observations largely correspond with the findings of the Erakonnad monitoring service (hosted by TNS Emor AS) that hint at the correlation between the intensification of the refugee quota debate, on EKRE's behalf, and the increase in the party's popularity from 2015 until $2018 .^{90}$ 
Table 3. Popularity ratings of political parties in Estonia (March 2016).

\begin{tabular}{lc}
\hline Political parties & Rate of popularity (\%) \\
\hline Centre Party & 25 \\
Reform Party & 23 \\
EKRE & 19 \\
Social Democrats & 13 \\
Free Party & 12 \\
Pro Patria and Res Publica Union & 6 \\
\hline Source: Turu-uuringute AS, https://www.postimees.ee/3637703/uuring-brusseli-terrorirunnak-tostis-ekre- \\
toetuse-reformierakonna-kannule (accessed 10 June 2018) (22-28 March 2016; 1,000 respondents).
\end{tabular}

EKRE appears to have succeeded in convincing its target groups not solely that Estonia forms part of the larger refugee crisis throughout Europe but also about the preemptive character of its engagement. This largely consists of tentative correlations between the (increased) physical presence of Muslim communities and the future prospects for the import of terrorism and/or other asymmetric threats. In Martin Helme's words, "Global terrorism poses a security threat for Estonia but this is lower in comparison to Western Europe ... the number of Muslim immigrants from the Middle East and North Africa who are based in Estonia is small. However, the refugee quota arrangement, dictated by the EU, can generate perils in the immediate future." 91

EKRE has not explicitly adopted the "EUSSR"92 narrative, as espoused by various Eurosceptic actors, with regards to the fashion in which the EU allegedly imposes its directives. ${ }^{93}$ However, its leadership has occasionally alluded to tentative correlations between the EU and the Soviet Union. ${ }^{94}$ In contrast to the more abstract and metaphorical uses of such correlations by populist and radical right-wing parties elsewhere in Europe, the historical and sociocultural specifics can render this socio-psychological strategy a lot more appealing and successful inside the Estonian context. In this regard, EKRE's leadership has been capitalizing rather steadily on the disillusionment among certain cohorts of the electorate with the effort invested during Estonia's accession process to the EU (1990s) and the actual state of affairs inside the Union. ${ }^{95}$

\section{Conclusions}

EKRE is a party with an increasing appeal among the Estonian voters. The main objective of this case study was to position the party's universality vis-à-vis its embeddedness inside Estonia's political and sociocultural context. EKRE's political engagement includes three aspects that appear to be universal among the European populist and radical right: (a) anti-establishment rhetoric, (b) Euroscepticism and nativism, and (c) opposition to immigration and insistence on the hard borders principle. Throughout Europe, to varying degrees, the political engagement along these three pillars has enabled parties of the populist and radical right to fill in existing gaps and augment their popularity among their respective electorates.

Nevertheless, EKRE displays a set of distinctive specificities, in comparison to other populist and radical right-wing parties across Central and Eastern Europe, that result from its political engagement inside the Baltic/Estonian context. First, EKRE's geopolitical Euroscepticism is solidly embedded in the anxieties over Estonia's security status 
vis-à-vis Russia's disproportional leverage. Second, EKRE is characterized by a more pro-free market orientation that is aimed at safeguarding the interests of (small- and medium-size) Estonian entrepreneurs inside the highly antagonistic context of globalized capitalism. One can seek the origins of this policy pattern in pre-existing interpretations of the neoliberal consensus over the economy (1990s) as another trajectory that would enable the Estonian nation to decolonize from the Communist-era planning and reassume full control over the management of their country's economy. Lastly, EKRE is not a "radicalized" mainstream party and, unlike the Visegrad Four states, the Estonian party spectrum does not include any "radicalized" larger parties either. This has provided EKRE with plenty of room for campaigning over the refugee question and immigration.

EKRE appears to subscribe to the universal trend, among the populist and radical right across Central and Eastern Europe, to weaponize the refugee crisis. This is reflected in the internationalization of the party's engagement over this issue. Nevertheless, since the second half of 2015, EKRE has also been embedding its opposition to the EU's refugee quotas arrangement inside the more particularistic colonization and decolonization narratives of Estonian nationalism. In contrast to the more abstract and metaphorical uses of correlations between the USSR and the EU by populist and radical right-wing parties elsewhere in Europe, the historical and sociocultural specifics can render this socio-psychological strategy a lot more appealing and successful in the Estonian context.

As becomes clear in this case study, the existing classification schemes for the European populist and radical right need to be updated and upgraded. In contrast to the older treatises on the populist and radical right in Central and Eastern Europe and their greater stress on the apprehension of these parties toward ethnic minorities, empirical research demonstrates that EKRE and other parties throughout the region have been seeking to augment their popularity along the systemization of anti-immigrant engagement. ${ }^{96}$ In particular, an emerging nexus that appears to be rather commonplace among parties of the populist and radical right in Central and Eastern Europe is the one that consists of domestic ethnopolitics, regional geopolitics, and "new" identity politics (namely, anti-immigration). This nexus, in turn, seems to be firmly anchored inside the Eurosceptic and anti-establishment agendas of these parties.

In all of this, it should be borne in mind that the trajectories toward capitalizing on anti-immigration sentiments have been rather idiosyncratic across Europe. Anti-immigration parties and groupings tend to embed their narratives primarily into symbols and imageries derived from their own societies' historical experiences. In this light, the cooperation between academic experts in nationalism and academic experts on the populist and radical right needs to become more extensive and systematic. On the one hand, this will enable experts in nationalism to assess more precisely the degree to which new variables such as Euroscepticism and anti-immigrant trends can reshape ethnopolitics, both as a living reality and as a field of study, across Central and Eastern Europe. On the other hand, this systematic cooperation will enable experts in the populist and radical right to formulate new interpretative models about how (right-wing) populist and Eurosceptic actors across this region embed their agendas inside the preexisting political cultures of nationalism and particularistic identity and memory politics. 


\section{Funding}

This article was authored courtesy of a Marie Curie Individual Research Fellowship-IF (Marie Sklodowska-Curie Actions) within the frame of Horizon 2020 (Project ID: 749400-MERWBKBS).

\section{Notes on contributor}

Vassilis Petsinis (PhD Birmingham) is a Marie Curie Experienced Researcher at the Johan Skytte Institute of Political Studies (University of Tartu). His individual project is titled: "Patterns and Management of Ethnic Relations in the Baltic States and the Western Balkans.”

\section{Notes}

1. Sidney Tarrow, "The Strategy of Paired Comparison: Toward a Theory of Practice," Comparative Political Studies 43, no. 230 (2010): 230-259.

2. Andrea L. P. Pirro, "Populist Radical Right Parties in Central and Eastern Europe: The Different Context and Issues of the Prophets of the Patria," Government and Opposition, 49, no. 4 (2014): 600-629; Bartek Pytlas, The Populist Radical Right in Central and Eastern Europe: Ideology, Impact, and Electoral Performance (London: Routledge, 2015); Michael Minkenberg, ed., Transforming the Transformation? The East European Radical Right in the Political Process (London: Routledge, 2015); Michael Minkenberg, The Radical Right in Eastern Europe: Democracy under Siege? (Basingstoke, UK: Palgrave Macmillan, 2017).

3. Daunis Auers and Andres Kasekamp, "Explaining the Electoral Failure of Extreme-Right Parties in Estonia and Latvia," Journal of Contemporary European Studies 17, no. 2 (2009): 241-54; Daunis Auers and Anders Kasekamp, "Comparing Right Wing Populism in Latvia and Estonia" in Right-Wing Populism in Europe: Politics and Discourse, edited by Ruth Wodak, Majid Khosravinik, and Brigitte Mral, (London: Bloomsbury, 2013); Daunis Auers and Andres Kasekamp, "The Impact of Radical Right Parties in the Baltic States" in Transforming the Transformation. The East European Radical Right in the Political Process, edited by Markus Minkenberg (London: Routledge, 2015); Siim Trumm, "The 'New' Wave of Populist Right-Wing Parties in Central and Eastern Europe: Explaining Electoral Support for the Conservative People's Party of Estonia," Representation 54, no. 4 (2018): 331-47.

4. Hans-Georg Betz and Carol Johnson, "Against the Current-Stemming the Tide: The Nostalgic Ideology of the Contemporary Radical Populist Right," Journal of Political Ideologies 9, no. 3 (2004): 311-27; Cas Mudde, Populist Radical Parties in Europe (Cambridge, UK: Cambridge University Press, 2007); Cas Mudde, "The Populist Radical Right: A Pathological Normalcy,” West European Politics 33, no. 6 (2010): 1167-86.

5. Alex Szczerbiak and Paul Taggart, eds., Opposing Europe? The Comparative Party Politics of Euroscepticism (Oxford, UK: Oxford University Press, 2008).

6. Trevor J. Allen, "All in the Party-Family? Comparing Far-Right Voters in Western and PostCommunist Europe," Party Politics 23, no. 3 (2017): 274-285; Minkenberg, The Radical Right in Eastern Europe; Pytlas, The Populist Radical Right in Central and Eastern Europe.

7. Lenka Bustikova, "The Radical Right in Eastern Europe," in The Oxford Handbook of the Radical Right, edited by Jens Rydgren (New York: Oxford University Press, 2018), 566-7.

8. Ibid., 568 .

9. Mihai Varga, "Hungary's Anti-Capitalist Far-Right: Jobbik and the Hungarian Guard," Nationalities Papers 42, no. 5 (2014): 791-807; Vassilis Petsinis, "The 'New' Far Right in Hungary: A Political Psychologist's Perspective," Journal of Contemporary European Studies 23, no. 2 (2015): 272-87.

10. Bustikova, "The Radical Right in Eastern Europe," 569. 
11. European Commission, "Enlargement: Accession Criteria," https://ec.europa.eu/neighbourhoodenlargement/policy/glossary/terms/accession-criteria_en (accessed 31 May 2019).

12. Lenka Bustikova, "The Democratization of Hostility: Minorities and Radical Right Actors after the Fall of Communism," in Transforming the Transformation, edited by Markus Minkenberg (New York: Routledge, 2015), 67.

13. On the case of Latvia, see: Li Bennich-Bjorkman and Karl. M. Johansson, "Explaining Moderation in Nationalism: Divergent Trajectories of National Conservative Parties in Estonia and Latvia," Comparative European Politics 10, no. 5 (2012): 8; Judith Kelley, Ethnic Politics in Europe: The Power of Norms and Incentives (Princeton, NJ: Princeton University Press, 2004), 83-84; Mark A. Jubulis, Nationalism and Democratic Transition: The Politics of Citizenship and Language in Post-Soviet Latvia (Lanham, MD: University Press of America, 2001), 128-29.

14. On FIDESZ, see: Ian Traynor, "Migration Crisis: Hungary PM Says Europe in a Grip of Madness," The Guardian, 3 September 2015. On SMER, see: Benjamin Cunningham, "Migrants Are Central Europe's New Roma," Politico, 4 May 2016.

15. Pirro, "Populist Radical Right Parties in Central and Eastern Europe"; Pytlas, The Populist Radical Right in Central and Eastern Europe: Ideology, Impact, and Electoral Performance, 600-629.

16. Trumm, "The 'New' Wave of Populist Right-Wing Parties in Central and Eastern Europe," 11.

17. Ibid., 10-11; Auers and Kasekamp, "The Impact of Radical Right Parties in the Baltic States," 146.

18. Trumm, "The 'New' Wave of Populist Right-Wing Parties in Central and Eastern Europe," 8-9 and 10.

19. Ernesto Laclau, Politics and Ideology in Marxist Theory (London: NLB, 1977), 175.

20. Cas Mudde, "The Five Best Books on Populism," interview by Sophie Roell, https:// fivebooks.com/best-books/cas-mudde-populism/ (accessed 10 June 2018).

21. Michael Hechter, "Alien Rule and Its Discontents," American Behavioral Scientist 53, no. 3 (2009): 289-310.

22. Ibid., 290, 292.

23. Ibid., 291.

24. Ibid., 298-99.

25. Epp Annus, "The Problem of Soviet Colonialism in the Baltics," Journal of Baltic Studies 43, no. 1 (2012): 21-45.

26. Annus singles out the following aspects that differentiate Soviet colonization in Estonia from the Western colonization of overseas dominions: (a) Estonia's legal status as a federated republic within the Soviet Union; (b) the lack of geographic distance between the colonized subject and the colonizing agent; (c) and the fact that the Estonians and the other two Baltic nations had already attained their national consciousness by the time of the Soviet annexation; ibid., 32-35.

27. Kalev Kukk, On Economic and Geographical Department of Estonia (1945-1990), Publications of the Estonian Geographical Society VI (Tallinn: Estonian Academy of Sciences, 1991), 8.

28. Piret Peiker, "Estonian Nationalism through the Postcolonial Lens," Journal of Baltic Studies 47, no. 1 (2016): 113-132. As a long-term consequence of the planned migration project, the Russian-speaking population in Estonia grew from 23,000 people in 1945 to 475,000 in 1991. These Russian-speaking settlers originated from various parts of the Soviet Union.

29. Sammy Smooha, The Model of Ethnic Democracy (Flensburg, Germany: European Centre for Minority Issues, 2001), 8.

30. Ibid., 24-25.

31. David Arter, Parties and Democracy in the Post-Soviet Republics: The Case of Estonia (Aldershot, UK: Dartmouth, 1996); Klara Hallik, "Nationalizing Policies and Integration Challenges," in The Challenge of the Russian Minority: Emerging Multicultural Democracy in 
Estonia, edited by Marje Lauristin and Mati Heidmets (Tartu, Estonia: Tartu University Press, 2012), 71.

32. Dovile Budryte, Taming Nationalism? Political Community Building in the Post-Soviet Baltic States (Aldershot, UK: Ashgate, 2005). In 1991, the bulk of post-war settlers in Estonia and Latvia, mostly Russian speakers, were rendered "stateless" and had to commence a long application procedure (including language tests) in order to obtain the citizenship of the newly independent republics.

33. Ivars Ijabs, "After the Referendum: Militant Democracy and Nation-Building in Latvia," East European Politics and Societies 20, no. 10 (2016): 13-15.

34. The People's Union was a partner in the large electoral coalition (the Estonian Coalition Union) during the second legislature (1995-1999) and then again between 2003 and 2007.

35. "The People's Union got a new name: Parliamentary parties are engaged in propagating the values of a morally dying European Union," https://www.delfi.ee/news/paevauudised/eesti/ uue-nime-saanud-rahvaliitparlamendierakonnad-tegelevad-manduva-ja-kolbeliselt-hukutavae uroliidu-vaartuste-propageerimisega?id=64124549 (accessed 31 May 2019).

36. Piret Ehin, "Estonian Euroskepticism: A Reflection of Domestic Politics?" East European Constitutional Review 11/12, no. 4/1 (2002/03): 96-100; Evald Mikkel and Andres Kasekamp, "Emerging Party-Based Euroscepticism in Estonia," in Opposing Europe? The Comparative Party Politics of Euroscepticism: Case Studies and Country Surveys, edited by Alex Szczerbiak and Paul Taggart (Oxford: Oxford University Press, 2008).

37. Auers and Kasekamp, "Explaining the Electoral Failure of Extreme-Right Parties in Estonia and Latvia," 241-254.

38. EKRE engulfed the predominantly rural electorate in the southern and western districts who used to opt for the People's Union in the past. In the 2015 elections, EKRE was the third strongest party in the western district of Pärnumaa. On this issue, see: "Hääletamis- ja valimistulemus hetkeseisuga," http://rk2015.vvk.ee/voting-results-12.html (accessed 22 June 2018).

39. Allan Sikk, "From 'Sexy Men' to 'Socialists Gone Nuts': The European Union and Estonian Party Politics," in The European Union and Party Politics in Central Eastern Europe, edited by Paul G. Lewis and Zdenka Mansfeldova (Basingstoke, UK: Palgrave, 2006), 43; BennichBjorkman and Johansson, "Explaining Moderation in Nationalism," 8-9.

40. Interview with the vice-chair of EKRE (12 October 2016).

41. The previous government coalition included the Reform Party, the SDE, and the Pro Patria and Res Publica Union. The current consists of the Centre Party, the SDE, and the ProPatria and Res Publica Union.

42. Vassilis Petsinis, "(Finally) Breaking the Deadlock? Estonian Presidential Elections 2016," Baltic Worlds, 24 October 2016, http://balticworlds.com/finally-breaking-the-deadlock/ (accessed 10 June 2018).

43. EKRE's program proposes an increase in the minimum wage and the state pensions that could guarantee a decent living ("Sotsiaalpoliitika" section). However, the party equally holds that the people's well-being must rely on the general development of the economy and not only on social benefits (including a pledge to recall unjustified pensions and benefits); ibid.

44. EKRE, "Conservative Manifest," https://ekre.ee/konservatiivne-manifest/ (accessed 7 June 2018).

45. Interview with the vice-chair of EKRE (12 October 2016).

46. Dario Cavegn, "Government Falls as Social Democrats and IRL Leave Coalition," ERR, 7 November 2016.

47. Silver Tambur, "Savisaar Suspended from Mayor’s Office," ERR, 30 September 2015.

48. Interview with an academic expert in Estonian party politics at the University of Tallinn (8 June 2016).

49. Juhan Kivirähk, "Kivirähk: What matters is not what you are talking about but what is being said," ERR, 26 March 2018. 
50. Merje Kuus, "European Integration in Identity Narratives in Estonia: A Quest for Security," Journal of Peace Research 39, no. 1 (2002): 98; Vello Pettai, "Unfounded Worries? Euroscepticism Prior to the Referendum's Mobilization," in Deciding on Europe: The EU Referendum in Estonia, edited by Vello Pettai and Piret Ehin (Tartu, Estonia: Tartu University Press, 2005), 41-62.

51. EKRE, "European Elections Platform," https://ekre.ee/eurovalimiste-platvorm/ (accessed 7 June 2018).

52. Ibid.

53. Ibid.

54. EKRE, "Konservatiivne Manifest."

55. EKRE, “Parliament 2015,” https://ekre.ee/riigikogu-2015/ (accessed 7 June 2018).

56. EKRE, “Conservative Programme," (“Majandus ja põllumajandus” section), https://ekre.ee/ konservatiivne-programm/ (accessed 7 June 2018).

57. EKRE, "Eurovalimiste Platvorm."

58. EKRE, "Konservatiivne Programm" ("Regionaalareng ja kohalik omavalitsus" section).

59. EKRE, "Eurovalimiste Platvorm."

60. In its program, EKRE vows to uphold "Christian family values and the traditional family model which consists of a father, mother, and children" ("Perekond' section").

61. Peiker, "Estonian Nationalism through the Postcolonial Lens," 121; Marje Lauristin and Peter Vihalemm, "The Political Agenda during Different Periods of Estonian Transformation: External and Internal Factors," Journal of Baltic Studies 40, no. 1 (2009): 9-11.

62. EKRE, "Konservatiivne Program” ("Kodanik ja Kodanikuühiskond” section).

63. Ibid.

64. Ibid.

65. Ibid.

66. Ibid.

67. Aili Vahtla, "Estonia Reaches First Refugee Quota," ERR, 14 March 2018.

68. Dario Cavegn, "Estonia Less than Enthusiastic about Proposed EU Asylum System Change," ERR, 7 April 2016.

69. Silver Tambur, "Migration Crisis Polarizes Opinions in Estonia," ERR, 22 May 2015.

70. Dario Cavegn, "Setback for Opponents of EU Migrant Distribution Plan," ERR, 12 September 2016.

71. EKRE, "Eurovalimiste Platvorm."

72. Silver Tambur, "Far-Right MP: We Will Deport Refugees If We Win Elections," ERR, 20 July 2015.

73. Aili Vahtla, "EKRE Wants Referendum on Migration Question," ERR, 6 October 2015.

74. Silver Tambur, "Poll: One-third of Estonians Support Accepting Refugees," ERR, 26 June 2015.

75. Moonika Oll, "Study: What Do Estonians Think of Migrants?" ERR, 20 November 2015.

76. Moonika Oll, "POLL: Estonians Distrustful of Government's Refugee Policy," ERR, 18 November 2015.

77. Aivar Voog, Arvamusuuring Eesti Elanike Hoiakutest Pagulastesse (Tallinn, Estonia: Kantar Emor, 2016), 8-12; "The General Attitude of Estonian Residents towards Migration and Refugees Has Significantly Improved," Valitsus, 6 December 2016.

78. On this issue, see the relevant diagrams at: "Väärtushinnangute uuring 2018," http://www. inst.ee/uuringud/vaartushinnangute-uuring-2018 (accessed 7 June 2018).

79. "EKRE to Stage Events in Support of European Anti-Immigrant Protests," ERR, 1 February 2016.

80. Vassilis Petsinis, "Contentious Politics in the Baltics: The 'New' Wave of Right-Wing Populism in Estonia," Open Democracy, 28 April 2016, https://www.opendemocracy.net/ author/vassilis-petsinis (accessed 10 June 2018).

81. Interview with the vice-chair of EKRE (12 October 2016).

82. Dario Cavegn, "EKRE Not Pleased about Arriving Refugees Accuses Government of Lying to the Public," ERR, 26 March 2016. 
83. Anthony David Smith, The Nation in History: Historiographical Debates about Ethnicity and Nationalism (Oxford: Oxford University Press, 2000), 82-83; Walker Connor, Ethnonationalism: A Quest for Understanding (London: Routledge, 1993).

84. Auers and Kasekamp, "Comparing Right Wing Populism in Latvia and Estonia"; Auers and Andres Kasekamp, “The Impact of Radical Right Parties in the Baltic States.” EKRE. 2013. "Bauska Declaration", https://ekre.ee/bauskadeklaratsioon/ (accessed 31 May 2019).

85. Trumm, "The "New' Wave of Populist Right-Wing Parties in Central and Eastern Europe," 11.

86. EKRE, "Eurovalimiste Platvorm."

87. Interview with the vice-chair of EKRE (12 October 2016).

88. Silver Tambur, "Migration Crisis Polarizes Opinions in Estonia," ERR, 22 May 2015.

89. Merike Teder, "Study: The terrorist attack in Brussels increased support for EKRE," Postimees, 31 March 2016.

90. TNS Emor, "Political parties trends," https://www.erakonnad.info/reiting.html (accessed 13 June 2018).

91. Interview with the vice-chair of EKRE (12 October 2016).

92. This term was originally coined by the former Soviet dissident and, later, hard Eurosceptic Vladimir Bukovsky. On this issue, see: Vladimir Bukovsky and Pavel Stroilov, EUSSR: The Soviet Roots of European Integration (Surrey, UK: Sovereignty Publications, 2004).

93. In February 2009, the former Czech President, Václav Klaus, accused the EU of an elitism and democratic deficit reminiscent of those encountered among the Soviet-era dictatorships. On this issue, see: "Boos as President Klaus Compares EU to Soviet Era Dictatorships," The Times, 20 February 2009.

94. Dario Cavegn, On 23 December 2017, Mart Helme expressed his unequivocal support for Catalan independence and stated that "... us who we have lived through gaining independence a quarter of a century ago, as a small country should recognize the aspirations of Catalans and not swear blind allegiance to Merkel and Juncker ... events occurring in Catalonia clearly characterize the agony of the European Union." On this issue, see: "EKRE Chairman: Estonia Must Support Catalonian Independence," ERR, 23 December 2017.

95. In accordance with an academic expert in Estonian party politics, "EU's pressures for the emergence of a multicultural society and exaggerated political correctness have sparked some opposition in Estonia. ... People who do not trust anyone and who want to protest against the ruling coalition, can choose EKRE" (interview with an academic expert in Estonian party politics at Turu-uuringute AS, 22 June 2018).

96. On Jobbik, see: Daniel Kovarek, Daniel Róna, Bulcsu Hunyadi, and Peter Krekó, "Scapegoat-Based Policy-Making in Hungary: Qualitative Evidence for How Jobbik and Its Mayors Govern Municipalities," Intersections 3, no. 3 (2017): 63-87. For the party's official position, see: "Immigration Increases Tensions in Europe," https://www.jobbik.com/ immigration_increases_tensions_europe (accessed 12 June 2018). 